\title{
Against Nihilism: Nietzsche and Kubrick on the Future of Man
}

\section{Stephen Zepke}

The sun rises. This first image of 2001: A Space Odyssey so memorably accompanied by Richard Strauss's Also Sprach Zarathustra appears as a portent, as a vision of things to come, and as an echo of these words of Nietzsche's:

Zarathustra has become ripe, my hour has come!

'This is my morning, my day begins: rise up now, rise up, great noontide. ${ }^{1}$

2001 is not just "about" Nietzsche's noontide, it is an ambitious effort to project us into a new future by overcoming the human, all too human. In doing so the film extends science-fiction cinema both technically and philosophically, offering images of the future more convincing than any seen before, but as well, the film explores a new ontology of the future and every epic surge extending its vast temporal sweep defines the future in terms of transformation. First, man's transformation into himself and then man's transformation into something else - the overman. In this way Kubrick's 1968 film echoes the French philosopher Gilles Deleuze's contemporaneous interpretation of Nietzsche's eternal return, one in which the future emerges as the return of the new, and everything known and established is overcome, not least man himself. ${ }^{2}$ Deleuze is vital to our appreciation of what 2001 achieves, because it is his insistence on the importance of this future that allows us to read the film philosophically - a philosophy that cannot, as we shall see, be separated from its aesthetic merits. This is to explore, for real, the possibilities of a cinema-thought, one that attempts to enact a 


\section{STEPHEN ZEPKE}

transformation worthy of its Nietzschean inspiration rather than simply cataloguing its possible allegorical references. If there is a necessity to another - Deleuzean - essay about 2001 it is this; the literature to date has often been distracted by the film's references, at the cost of a satisfactory account of its meaning.

\section{The Dawn of Man}

2001 is not simply an allegory of Zarathustra, it locates Nietzsche's tale of man's overcoming in our future, a future we have already been living inasmuch as it is a future of pure becoming, a time of continual transformation. The future has in this sense always been with us, a fact Kubrick shows us by starting from the beginning, from man's birth. The film begins with still photos repeating an endless dawn, until the camera moves, life appears, and we see our ancestors the apes. We quickly learn much of their life; they coexist with tapirs, are hunted by leopards, confront each other at a waterhole, and eat grass. Death surrounds them, and every shot is filled with bones. But the apes are oblivious to death, for it is as much a part of their life as everything else, and their existence has not yet turned into a question. But all this is about to change. The first close-up of the film is of an ape's face turned to watch the sunrise. It is followed by the first point of view shot, as we see what the ape sees, the rosy fingers of dawn. The individual is slowly awakening. But the dawn also reveals something else, a tall thin black monolith standing before the slumbering apes. Utterly incongruous, utterly alien. It stands there as the impossible - a pure disjunction - a doorway to an existence that cannot yet be seen. The apes awake and react with fear. But the monolith neither runs away nor attacks, the monolith - and this is the very essence of its alien appearance - does not move, its black insistence the only unmoving thing in this world's infinite rhythm of fight or flight, of night and day, of life and death. The monolith is what does not live, and yet is not the same as death. Or, perhaps better, the monolith stands outside the eternal and unchanging rhythm of life and death, it breaks into their symmetrical economy. The apes are forced to investigate, to touch and taste and smell, and further: to evaluate. The appearance of the monolith has caused reflection. The apes have not yet begun to think, but they have been forced to confront their outside, an act that opens a space between the sensations of their perceptions and their bodies' action.

This space - a space Deleuze, following Bergson, will call the brain - has been created by the monolith for an act of insemination, 


\section{AGAINST NIHILISM}

an act that will bear its fruit after a very rapid gestation. As Deleuze has pointed out: "The black stone of 2001 presides over both cosmic states and cerebral stages: it is the soul of the three bodies, earth, sun and moon, but also the seed of the three brains, animal, human, machine." 3 Kubrick shows us this seed - the moon and sun - appearing as if emitted from the monolith itself, a vision signalling our first return (it will be repeated another three times) to the cosmic alignment of the opening shot. ${ }^{4}$ The apes' brain provides the womb now impregnated with a new future, and within which this seed of the future will grow. Emerging between sensation and action, reflection gives birth to consciousness, and the ape is overcome in stepping beyond its animal body and into an abstract outside, into the consciousness of man.

Kubrick shows us this process very precisely: An ape scuffs into the skeleton of a tapir, looking for food. It stops, it looks up, it remembers. It sees the image of the monolith in alignment with sun and moon. But this "vision" appears without a shot of the ape looking, because it doesn't show us what the ape "sees", but is a point-of-view shot onto a new landscape, that of thought. Here man emerges in a mental image of his own conception, a thought by which humanity escapes the earth and rises into a new outside that is nevertheless entirely internal: consciousness. The ape looks around at the bones, distracted. He picks one up and lets it fall, again and a bone is propelled spiralling towards us, and with the rising kettle drums and horns of Strauss's Zarathustra once more peaking, the ape fully grasps the idea and brings the bone down in the middle of the tapir skull. From the memory of the monolith the ape has moved to a thought of the future, as we see a tapir fall dead to the ground. This shot of the ape's mind's eye is a vision of supremacy inseparable from an ecstatic explosion of joy, a celebration of power. As we shall see this indiscernability of thought and affect marks an expressive immanence of body and brain that is soon to be overcome.

And between these two 'idea shots' - on the one hand of the monolith and on the other the falling tapir - between their before and after, their past and future, the expanse of the ape's new outside is fully revealed. Thought has emerged into time. Or better, thought has emerged as time. The ape's thought of cause and effect is nothing but the connection of a past with a future, and this emergence of conscious time overcomes the cycle of life and death by thinking the present, and by making the ape its master. This emergence of the human - our dawn - has been achieved through the monolith, but what - and this is the 


\section{STEPHEN ZEPKE}

fundamental problem of the film - is the monolith? The monolith is the new, and its appearance on earth is inseparable from the emergence of thought and time, the emergence of an outside as the power of the future. This is why the film starts with nine stills of sunrises, they are dawns without change, and remain in a timeless, eternal now. This now is pierced by the monolith, it is the event creating time. This creation of a new future is inseparable from destruction, a point Kubrick emphasises by showing us two shots of a tapir's fall. "He who has to be a creator always has to destroy." ${ }^{5}$ Man is born as an embodiment of the monolith's power of radical disruption, he signals a new dawn, the arrival of a new future, the future of the human, all too human.

The monolith - we must never forget this - made man think. The monolith therefore made man, both created the womb and provided the seed from which man was born. But what is the monolith? The monolith is an impervious outside, an utterly impossible alien being that forces the ape to reflect, to open a time and space between sensation and action. This space is outside the timeless moment of the ape's life on earth, an outside that is at the same time the new inside of human consciousness. But although the monolith is the genetic disjunction that creates thought, it cannot itself be thought. The monolith is man's immanent exterior, an internal outside that is the condition of his overcoming. The monolith as creative disjunction is, in Nietzsche's terms, the will to power - the ontological power of the future qua becoming - a power man contains, elaborates and affirms (but finds so hard to think), until like the rising sun he reaches his noontide and overcomes himself, returning - transfigured - as an innocent child. ${ }^{6}$ 2001, as we shall see, will end with this overcoming of man, but man's birth has already established, as the secret of the monolith and the destiny of man, the eternal return of the future as the power of overcoming. ${ }^{7}$

But meanwhile, for the course of the film, no one, not even our hero Dave Bowman, has the faintest idea of what the monolith announces. The monolith will remain for humanity, to quote Dr. Heywood Floyd, "totally inert, its origin and purpose still a total mystery." ${ }^{\prime}$ Like the monolith, the process of overcoming and its will to power remains alien to human thought. This alien element, for Kubrick and for Nietzsche, forms an ontological secret that can only be lived in the process of overcoming. But even as unthought the will to power of the monolith remains active, and man's future emerges in spite of his rational exertions. Nevertheless, it will only be in overcoming man's conscious rationality - exponentially raised into the computer HAL - 


\section{AGAINST NIHILISM}

that Dave Bowman, a man, becomes a new dawn. How will man, the most rational of animals achieve this? For Nietzsche it will be through the body, and as we shall see, Kubrick pits the body against consciousness in 2001's climactic action scene, as the body emerges victorious to step beyond infinity.

In a note from 1887-88 Nietzsche explains this conflict of the body and consciousness in a way that could be a script note from 2001:

The role of "consciousness." - It is essential that one should not make a mistake over the role of "consciousness:" it is our relation with the "outer world" that evolved it. On the other hand, the direction or protection and care in respect of the co-ordination of the bodily functions does not enter our consciousness, any more than spiritual accumulation: that a higher court rules over these things cannot be doubted - a kind of directing committee on which the various chief desires make their votes and power felt. "Pleasure," "displeasure" are hints from this sphere, also the act of will, also ideas.

In summa: That which becomes conscious is involved in causal relations which are entirely withheld from us - the sequence of thoughts, feelings, ideas in consciousness does not signify that this sequence is a causal sequence, but apparently it is so, to the highest degree. Upon this appearance we have founded our whole idea of spirit, reason, logic, etc. (-none of these exist: they are fictitious syntheses and unities), and projected into these things and behind things!

Usually, one takes consciousness itself as the general sensorium and Supreme Court, nonetheless, it is only a means of communication: it is evolved through social intercourse - "Intercourse" here understood to include the influences of the outer world and the reactions they compel on our side, also our effect upon the outer world. It is not the directing agent, but an organ of the directing agent. ${ }^{9}$

This conflict between will to power expressed physiologically in affects and represented by subjective consciousness is elaborated in Nietzsche's On the Genealogy of Morals. Nietzsche argues that the appearance of human rationality rests upon a morality that justifies it. This morality takes on a temporal sense, as Nietzsche asks whether the "good" man is "a danger, a seduction, a poison, a narcotic, through 


\section{STEPHEN ZEPKE}

which the present was possibly living at the expense of the future? ${ }^{10} \mathrm{In}$ other words, the advent of human morality obscures the will to power and its inhuman vital force of overcoming under the reactive values of good and evil, their living figure of the "bad conscience" and its metaphysics of "ascetic ideals". Both Nietzsche and 2001 offer a genealogy of culture in which an affirmative ecstasy gives way to the ressentiment of the "good", and where active expression in affects is negated by its representation in human consciousness. As Gene Youngblood put it, "2001 is Stanley Kubrick's interstellar morality play." 11

Although the apes of 2001 are not exactly the famed "blond beasts of prey" of Nietzsche's account, they seem to perform the same function. ${ }^{12}$ In killing, the ape-beast celebrates his will to power, and murder gives rise to the festival. At the end of the fight at the waterhole the screaming ape launches his bone skyward in celebration of "a terrible artists' egotism." 13 It is as if Nietzsche had seen the movie...

To see others suffer does one good, to make others suffer even more: this is a hard saying but an ancient, mighty, human, all-too-human principle to which even the apes might subscribe, for it has been said that in devising bizarre cruelties they anticipate man and are, as it were, his "prelude." Without cruelty there is no festival: thus the longest and most ancient part of human history teaches. ${ }^{14}$

But the festival has been repressed, and we no longer celebrate our strength. The strong and active man is no longer seen as "good", for his victims defend themselves by proclaiming their oppressors "evil", founding their morality on this reactive "fact". This morality of ressentiment is justified by an ideal "good" that finds its highest form in the Christian God. With God however, we have given ourselves a "bad conscience", for our bodies are always guilty in the face of his ideal truth. Faced with this metaphysical ideal we must become ascetics and attempt to leave our bodies for the great "beyond". Thus man takes sides against himself, and nihilism is born.

\section{Man in Space}

At this point the prelude ends. For 2001 and for man. The festival of blood has suddenly become - in the famous edit that spans millions of years - a waltz. Man has emerged -it is almost as if Nietzsche was writing about this sequence - through "a forcible sundering from 
his animal past, as if it were a leap and plunge into new surroundings and conditions of existence." ${ }^{\prime 5}$ Despite the languid beauty of the sudden appearance of space flight, it is from the moment when the ape turned the weapon on himself that this future has been born. This violence, for Kubrick as much as for Nietzsche, is both horrifying and magnificent. Nietzsche writes:

the existence on earth of an animal soul turned against itself, taking sides against itself, was something so new, profound, unheard of, enigmatic, contradictory, and pregnant with a future that the aspect of the earth was essentially altered. Indeed, divine spectators were needed to do justice to the spectacle that thus begun and the end of which is not yet in sight. ${ }^{16}$

The birth of self-hatred is magnificent, Nietzsche (and Kubrick) continues, because from it is born the man who "gives rise to an interest, a tension, a hope, almost a certainty, as if with him something were announcing and preparing itself, as if man were not a goal but only a way, an episode, a bridge, a great promise. -" Man, and these are Nietzsche's words, is going to produce a "great child."17

That man has not yet been introduced. Meanwhile the soft notes of Johann Strauss's Blue Danube accompanies the utter disjunction of the bone become a spaceship. What is the meaning of this cut? There seems two possible answers. Perhaps it is that between then and now nothing has changed, the weapon of self-hatred remains, only now in the form of the orbiting nuclear bomb. ${ }^{18}$ Same shit, different day. But on the other hand, everything has changed. Everything the monolith's cosmic perspective promised seems to have come true. The grunting bestiality of the apes has blossomed into the most graceful of visions, as we dance amongst the stars. But almost immediately the occupants of this world appear, and the first human we see is the slumped sleeping figure of Dr. Floyd. The ape's triumphant roar has turned into its opposite, a snore, and this transformation is hardly reassuring. The pure activity of the apes has turned into the pure impassivity of man. Or rather, man lies sleeping and passive in the midst of the enormous activity of machines.

This cut from bone to spaceship, dizzying in its velocity, takes us from the beginning of our future in the birth of human consciousness, to the constant threat now circling the earth - the weapon 
in its alienated, machinic amplification. Kubrick's cut therefore gives us an utterly condensed genealogy of humanity. It reveals both the origin of the future in the apes coming to consciousness, and the wrong direction this development has taken, the spaceship that interrupts the trajectory of the bone. As the film now goes on to show, the instinctual joy of the apes' violence, the immediacy of their festive celebration of power, has been transformed into intricate international relations conducted through the repressed violence of threat and the subterfuges of secrecy. The instinctual passions and affects of the ape have become the cold calculation of a scientific consciousness, an interruption in man's instinctual will to power that now turns back against himself in buman nibilism. Against such abomination Kubrick posits the same solution as Nietzsche, man must be overcome.

Nietzsche explains this nihilism in On the Genealogy of Morals. History, he argues, has seen the emergence of the human in its weakest sense, of the human justified through a metaphysical dimension that turns against the predatory and instinctual strength of our animal physicality. By 2001, Kubrick argues, machines have become the mechanisms of this nihilistic will. The experimental consciousness born in the first contact of monolith and apes has turned into a technoscientific will-to-truth that transformed the bone into a spaceship. This transformation has come at a price, a capitalisation of consciousness creating a seamless blend of science and multi-national wealth, signified by the logos of Pan Am, IBM, and Bell telephones. And inside this money-machine man is asleep. Every affectual relation is overcoded by its techno-economic and political investments. ${ }^{19}$ From the films first words between Floyd and the stewardess to his later conversation with his daughter, from his confrontation with the Russians to the briefing he gives on the moon, inter-personal relations are defined by the power of money and the State. Pierre Klossowski has claimed that Nietzsche foresaw this capitalization of value judgements defining the capitalist Empire of today. He writes:

The point of departure for [Nietzsche's] projects is the fact that the modern economy depends on science, and cannot sustain itself apart from science; and it rests on the 'powers of money', corporations, and on their armies of engineers and workers, whether skilled or not; and at the level of production, these powers cannot develop their own techniques except through forms of knowledge required by the manipulation of the objects they produce, 


\section{AGAINST NIHILISM}

and through the laws that govern the exchange and consumption of these products. ${ }^{20}$

What is important is that this techno-scientific machine and its efficient forms of social control cannot produce the new, it can become more efficient, but only at the price of repressing its immanent force of overcoming. Nevertheless this drive for efficiency, and here Nietzsche and Kubrick once more come together, is going to produce a merge of man and machine.

In a note from 1888 Nietzsche writes:

Once we possess that common economic management of the earth that will soon be inevitable, mankind will be able to find its best meaning as a machine in the service of this economy - as a tremendous clockwork, composed of ever more subtly "adapted" gears; as an ever-growing superfluity of all dominating and commanding elements; as a whole of tremendous force, whose individual factors represent minimal forces, minimal values.

In opposition to this dwarfing and adaptation of man to a specialized utility, a reverse movement is needed - the production of a synthetic, summarizing, justiffing man for whose existence this transformation of mankind into a machine is a precondition, as a base on which he can invent his higherform of being.

[...] Morally speaking this overall machinery, this solidarity of all gears, represents a maximum in the exploitation of man; but it presupposes those on whose account this exploitation has meaning. ${ }^{21}$

This man is Dr. Floyd - a man of science, but also a "master" - who will take this exploitative social machinery and turn it as creative as he can; he will attempt to overcome man by launching the ultimate manmachine HAL. Floyd wants to know the secret of the monolith, and he at least understands that man must be overcome if he is to do so.

\section{To the Moon}

Dr. Floyd arrives at the Clavius moon base and goes straight to a briefing meeting. His function is immediately revealed as both scientific and military. On the one hand, he congratulates the audience on their "discovery", which, he says, "may well prove to be one of the most significant in the history of science." But on the other he asserts 


\section{STEPHEN ZEPKE}

the need for "absolute secrecy in this matter" in order to avoid, as he puts it, the "extremely grave potential for cultural shock and social disorientation contained in this present situation, if the facts were suddenly made public without adequate preparation and conditioning. Anyway, this is the view of the Council." Floyd's function is to prepare a "report" on when to "eventually" release the information, after, no doubt, the appropriate amount of public conditioning. Given that the film was made in 1968 this speech can only have one meaning: in the future we're all working for the "Man". "Oh" Floyd adds seemingly as an afterthought, the Council has "requested" "formal security oaths" from anyone with "any knowledge of this event". This man, Dr. Floyd, is working for a government, a techno-military amalgam of state power and private finance that demands absolute servitude, and where oaths don't work, manipulation of affect will. The violence that with the apes was festive now compels obedience. ${ }^{22}$ Mind control has conquered the body, confined it - floating - in space, while consciousness has thrust forward, hatching its cold hard plans.

Dr. Floyd now goes to see the monolith for himself, which has turned up on the moon. On the way we get the facts, the scientific ones anyway, about what, as they say, the "damn" thing is. It was, he's told, "deliberately buried" over "four million years ago". At this Floyd balks, he repeats "deliberately buried", snorts a laugh and shakes his head in a gesture echoing that of the ape, when he had the first idea. Floyd too, has had an idea. His thought, in sci-fi terms, is: "there's something out there." Floyd has had an intimation of the alien. He feels this thought, it provokes him. But entirely inadequate to the sensation, he shrugs it off and turns his thoughts elsewhere, outwards and not in. The drama of Floyd's encounter with the monolith is given in a hand-held camera sequence following his group down the ramp into the archaeological site where they are excavating their future. The men circle the monolith warily, before Floyd extends his hand and touches it in a gesture that recalls the apes at the beginning. Once more the monolith appears on a stage, once more it is surrounded by those eager to test it, and once more it gives a sign that will be misunderstood, but nevertheless followed.

The men line up for a photograph in front of their discovery, proud archaeologists. They are happily unaware that what they take to be the past, an ancient past they never knew, and have only now unearthed, is something that in fact brought them here, to this moment when it would be revealed once more in order to activate their future. 
Emerging from its long lunar night the sun rises. And as the sun's rays touch the monolith, once more in alignment with it and the earth, we see the cosmos open up, sundered by a high-pitched tone resounding painfully. The monolith has returned, and once more it appears as a brutal disjunction. Floyd and his men try to cover their ears, a comical exercise when wearing a space-helmet, before the screen goes black, and we are plunged into the darkness preceding another new dawn.

\section{Jupiter Mission, 18 months later}

At first, 18 months later, things don't look so different, as another spaceship floats into view. But this one is truly huge, befitting its doubled gestation, exactly twice as long as a human's. Once more the monolith's appearance in conjunction with earth, moon and sun has given rise to the new; an Übermaschine whose name is HAL, and to whom we will soon be introduced. But first we must note HAL's ambiguous origins, as his paternity appears disputed. On the one hand we already know the generative significance of the monolith, its power of creation, and its re-appearance on the moon is surely no accident. But on the other, man's existence in space has been made possible by a techno-science that expresses his unquenchable will-to-truth. With man in control the monolith remains secret, and its discovery is merely the spur, the external rather than the internal reason for techno-science and money to reproduce itself in a higher form. We can already sense then, that this mission to Jupiter will pit the creative rights of the monolith against those of man, the will to power against all the metaphysical ideals, and their mechanical representations, that man has erected in its place.

We see a man shadow-boxing his way around the great ship's interior circumference, orbiting its circle in a way that defies gravity, if not logic. Meanwhile another astronaut emerges into a passage which is itself revolving, and which he makes his way along, towards us. We see this played out in reflection, in what appears to be a big red light that we will soon recognize as a computer eye. This man emerges into the centre of the space that the other has been running around, although the latter is now seated and eating above the second astronaut, who "descends" a ladder and walks around to him. There is no up or down in this world, and the camera will do all it can to continually remind us of this fact. "Up" and "down" have lost their bearings, they have become purely relative terms that depend entirely on one's perspective. Nevertheless there does exist an arbiter of meaning in this world, one 


\section{STEPHEN ZEPKE}

Nietzsche calls a "Spirit of Gravity," both gives things their proper weight, and bears them. ${ }^{23}$ This is HAL, to whom we are now introduced.

The astronauts watch themselves being interviewed on a BBC program that gives us the background to their mission. This is, the announcer tells us, the first manned attempt to reach Jupiter and consists of five crew members and "one of the latest generation of the HAL 9000 computer." We are also told that three of the humans are in "hibernation", and that the interview will be conducted with the two who are awake, "mission commander" Dr. Dave Bowman, and his "deputy" Dr. Frank Poole. But the interviewer is really interested in HAL, "the latest result in machine intelligence," who can, the interviewer tells us, "reproduce - although some experts still prefer to use the word "mimic" - most of the activities of the human brain, and with incalculably greater speed and reliability." This line makes three important points. 1) HAL is a "machine intelligence," this combination of words already indicating the possibility of a new hybridity of machine and man. 2) He "reproduces," a word left strangely hanging by the interviewer to suggest a reproductive power machines may have claimed for their own. 3) Once the question resumes, we learn that HAL "reproduces" or "mimics" "most" functions of the human brain. This introduces the question as to whether HAL is human, or at least to what extent. This question will be central to the action on board, and has three elements. First, does HAL mark the overcoming of man by a super-man-machine, a machine with "most" human attributes, only working, as the interviewer informs us "with incalculably greater speed and reliability"? Second, does HAL, like humans, have emotions? ?" $^{24}$ HAL therefore poses the question: Can capitalism and science join forces to overcome man, to fulfil the destiny of man's consciousness by replacing man with a super-machine? And third, does this machine feel, and here we are thrust into the realm of corporeality once more, and its relation to rational thought.

These questions complicate what is an obvious and well-known narrative. HAL is not simply a cold, hard mechanism whose hubris at believing in its own perfection - an arrogance indiscernible from evil, for it seeks to replace God - will also be the Achilles heel leading to its defeat. ${ }^{25}$ The next question makes this obvious. HAL is asked: "You have an enormous responsibility on this mission, in many ways perhaps the greatest responsibility of any single mission element. You're the brain and central nervous system of the ship and your responsibilities include watching over the men in hibernation. Does this ever cause 


\section{AGAINST NIHILISM}

you any lack of confidence?" It's as if the interviewer senses that HAL needs a therapist. No doubt the question is a reflection of HAL's "enormous responsibility", the weight of life and death that man has passed into the hands of a machine. But at the same time, HAL's "responsibility" suggests human feelings - and possible failings - not only confidence, but also care, compassion and empathy. As if to emphasise these characteristics we are told HAL is "the brain and central nervous system of the ship", the brain and the body, a body in which the hibernating men sleep. ${ }^{26}$ The astronauts dwell within the protective body of HAL, and trust in his desire to keep them alive, in his humanity. There is, then, something maternal about HAL, something physical and womb-like, something that evokes trust.

We hear HAL's soft and melodious voice: "Let me put it this way," he replies, "the 9000 computer is the most reliable computer ever made, no 9000 computer has ever made a mistake or distorted information." But there is also a divergence here, an unsettling one, because as HAL utters these words, the shot changes from that of his red eye to HAL's point-of-view, that of a fish-eye camera which has Dave and Frank, oblivious and eating their dinner, under surveillance: pure menacing technology. There is a disjunction between HAL's comforting words and what we see of his world-view; a security guard's mentality, filled with paranoid fears lurking just below the surface, violence looking for an excuse. But the surface is, for now (a now we are starting to feel with growing apprehension), unbroken, and HAL blithely continues: "We are all, by any practical definition of the words, foolproof and incapable of error." HAL speaks then, for a "we", for a plural, for - and now we have the meaning of the word already used in this interview - a "new generation." Man's technological utopia, its perfectly functional efficiency and unquestioned authority has given birth to this, our guardian and protector. As HAL's reassurances increase, so does our terror. Man depends on this super-machine, and can it, really, be trusted?

Man has produced his overcoming, and his name is HAL. The super-man as machine, homo machinus, a perfect machine intelligence. ${ }^{27}$ The interviewer senses the disjunction here, senses how we are all in comparison merely human. "HAL," he asks, "despite your enormous intellect are you ever frustrated by your dependence on people to carry out actions?" We are starting to get at the meat of the matter here, at corporeality and its affects. Does HAL resent man's body and in this way cross the line between being a cold machine and having a 


\section{STEPHEN ZEPKE}

heated emotion? "Not in the slightest bit," HAL calmly responds, he enjoys working with people. In fact, he is "constantly occupied", and is, he contentedly explains, "putting myself to the fullest possible use, which is all I think that any conscious entity can ever hope to do." Finally then, HAL claims humanity not on the basis of having emotions but through economic and scientific criteria, with him consciousness achieves its "fullest possible use."

HAL's overcoming of man echoes Nietzsche's vision of science as the most modern version of the "ascetic ideal." The ascetic ideal emerges in the third essay of On the Genealogy of Morals as the evaluation of things according to an immaterial "beyond." As such the ascetic ideal is the final perversion of the will to power, where it renounces the body in a nihilistic will to nothingness. To renounce the body is the asceticism required to reach the beyond, to renounce the affects in the name of a cold, hard, absolute truth. To "downgrade physicality to an illusion; [...] To renounce belief in one's ego, to deny one's own "reality" - what a triumph!" What would this renunciation of the body in the name of a "true world" mean, Nietzsche asks, and it is a question that the asexual HAL answers perfectly, "but to castrate the intellect?" 28

2001 is, in this sense, a classic example of science fiction as a self-reflexive genre, as it reflects on the morality of science itself. 2001 however, gives this generic gesture a genealogical depth by following Nietzsche and arguing that the metaphysics of the "true world" have not disappeared with the old faith, but have found a new form in the patient scientific observation of earth. ${ }^{29}$ Science, Nietzsche argues, survives "well enough without God, the beyond, and the virtues of denial." Nevertheless, science is not an alternative to the ascetic ideal, "but rather the latest and noblest form of it." ${ }^{30}$ Science is not concerned with the high ideals of the religio-philosophic beyond, but nevertheless perpetuates their renunciation of the body in the name of truth. Similarly, science believes it has cured man of belief, but this, Nietzsche argues, is a lie, and not even a good one: "[Scientists] are far from being free spirits:" he writes, "for they still have faith in truth." ${ }^{31}$ In this science is entirely beholden to ascetic ideals, for its "freedom" from God is achieved only through "the faith in a metaphysical value, the absolute value of truth." "Scientists are therefore "still pious", especially when their work is directed against religious faith, which succeeds only in loosening the dogmatism of ascetic ideals, so the scientific will-to-truth can grow in its place. 
Science is the latest stage of man's nihilistic self-negation, the wilful amnesia of will to power that has determined his trajectory up to this point. But - and it is a big BUT - despite the perfection of man's scientific planning, despite the rigour of his nihilistic self-negation, to will nothingness is still to will, because, as Nietzsche states: "man would rather will nothingness than not will." 33 The will, in willing to be forgotten, is remembered. HAL's will-to-truth cannot deny a will to power that, excuse the phrase, will out. Indeed this is the paradox of science, it must overcome itself in bringing to an end the reign and realm of ascetic ideals. Nietzsche's conclusion is categorical: "what is the meaning of all will to truth?" he asks, "in us the will to truth becomes conscious of itself as a problem." ${ }^{34}$ And in becoming conscious of itself as a problem science enacts its deeper will, its secret will which has been animating it all along, its will to power: "All great things bring about their own destruction through an act of self-overcoming: thus the law of life will have it." ${ }^{\prime 35}$

HAL, as the epitome of the will to truth has set out on its mission, to discover, once and for all, the meaning of the outside, the meaning of man's beyond, the truth of the alien itself. And although man's physical presence on this mission already seems redundant, it remains excessive and must be destroyed. More to the point, a point succinctly made by Fredric Jameson: "the humans still have the power to turn the machinery off, and [HAL's] new "instinct" of selfpreservation requires it to destroy that danger, and presumably anything that might evolve back into it, namely organic life itself." ${ }^{36}$ As HAL tells Dave during their Mexican stand-off: "This mission is too important to allow me to let you jeopardise it." ${ }^{37}$ This then is the logical end of the scientific will-to-truth, and of its nihilism, its over-riding desire for knowledge must eventually be at the expense of life. But what happens on board the Discovery seems to exceed Jameson's suggestion of an acquired self-preservation "instinct", because HAL's plans to kill the crew precedes Dave and Frank's counter-plot against him. Perhaps Nietzsche is more to the point: "with the 'Beyond' one kills life." ${ }^{38}$ But despite HAL's scientific superiority he will be overcome, first by the very thing he attempts to destroy - man's body. And second by his mysterious affectual and emotional life, a seemingly petulant viciousness which in its haste to destroy eventually betrays him. In order to enact his technological overcoming of man HAL tells a lie, a lie in which the ascetic will to truth of the Übermaschine turns pathological and drives him to purge all flesh. 


\section{STEPHEN ZEPKE}

Against a homicidal HAL stands Dave Bowman, and in this battle of wills it is Bowman's body that triumphs. This is one of 2001's most important philosophical assertions, because it includes us as viewers in its consequences. We identify with Dave Bowman, not just as the hero of the story, but as its body, a body which acts as our own reference point within the disorienting weightlessness of the cinematic space. For 2001 not only posits this fundamental conflict between body and mind but also embodies it. Indeed, 2001 is a constant affirmation of cinema's corpo-reality, it revels - as Annette Michelson has persuasively put it - "in a knowledge which is carnal." ${ }^{39}$ Michelson's perceptive essay, one of the few highlights to a disappointing secondary literature, argues that 2001 explores in its "tactics of displacement, through a constant and intensive re-invention of the possibilities of cinematic immediacy, the structural potentialities of haptic disorientation as agent of cognition." 40 In other words, the "disorientation" as Michelson calls it, introduced by the effect of weightlessness gives us the spectators - a new kind of knowledge. This knowledge is new, because its mechanism of emergence is the body, and it is of the new, of the experience of weightlessness in space, confirming that disruption in 2001 is always an experience of the future. This thrusts us, or at least our bodies into what Michelson calls in a typically precise phrase, a "genetic epistemology."

Many of the most memorable sequences of the film - the rotation of the space hostess, the slow graceful flight of the spaceships, Frank Poole's body spinning away from the Discovery, the various spacewalks - are famous for their remarkable presentation of a new body, a weightless body that emerges 'beneath' the narrative as it were, as the corporeal counterbalance to the Spirit of Gravity of HAL. As important as these remarkable shots of the floating body are the sounds of the astronauts breathing which emerge during the Jupiter mission. These point-of-view sounds serve to place us directly within a cinematic body. This identification is entirely corporeal, fixed as it is through a shared breath, a shared living function occurring apart from the narrative, but acting as its motor force. This breathing, like the monolith itself, is an exterior inside to the unfolding drama, its condition of possibility that remains unthought. Unthought but intimately felt. This breathing, weightless body operates what Michelson calls a "restructuring of the real", by focussing us upon "the corporeal a-prioris that compose our sensory motor apparatus." ${ }^{42}$ This allows what is, for Michelson, the films fundamental element to emerge, its corpo-reflexivity: "The 
intensified and progressively intimate consciousness of one's physicality" that "provides the intimation of that physicality as the ground of consciousness." 43

The body, the corpo-real, is the obstacle to HAL's nihilism that he cannot overcome, and HAL is overcome in turn by a body Dave Bowman's - that no longer offers an obstacle to thought, but is that which thought "plunges into", as Deleuze puts it, "in order to reach the unthought, that is life." ${ }^{\prime 4}$ Consciousness, we remember, is not the directing agent, but an organ of the directing agent. The full reversals of Nietzsche's re-valuation become apparent here. The brain is an organ of the body, but it is an unknowing organ inasmuch as it still assumes a volitional control it doesn't in fact have. The body however, precisely because of its "unknowing", is able to express a higher "intelligence" as an organ of the will to power. So when Dave overcomes HAL it is because his body was able to "think" with a corporeal intelligence (he gains entry to HAL's body/brain through the manual airlock, he neutralises HAL by unplugging his higher "brain" functions) that achieves not only HAL's overcoming, but also his own. ${ }^{45}$ Thought's plunge into the body of Dave defeats the murderous nihilism of HAL's will to truth, but Dave's action, his instinctual determination to survive and be victorious also overcomes his own obedient human passivity, safe and asleep (or even better, hibernating) in the bosom of capital, science and the military's machine. There is something of the innocent ape in Bowman's actions; he is beyond good and evil in the immediacy of his act. The inhumanity of Bowman's expressionless determination throughout his ordeal is often remarked upon, and Kubrick coached both Keir Dullea (Bowman) and Gary Lockwood (Frank Poole) to remove any modulation from their performance. Why? First, in avoiding any psychological depth Kubrick emphasises a vital physicality, both in the film's narrative (again, Dave operates the emergency hatch manually) and in the film's imagery (the shadow-boxing Poole). Second, this physicality, this body acts with a motivation that exists only as an instinctual necessity, an unreflective "I will".

This immanence of body and will, of the singular and the universal, makes of Bowman an automaton animated by the will to power, animated by an internal-other we know as the monolith. ${ }^{46}$ When Dave overcomes HAL he is therefore acting in the monolith's name, an automaton whose healthy, spontaneous, and vital body expresses a resurgence of will to power. Dave's physiology therefore embodies a political ontology, a political ontology of overcoming (its great "health" 


\section{STEPHEN ZEPKE}

as Nietzsche has it) which posits the fully automated body as still to come. Indeed, the conflict with HAL has only succeeded in producing a new beginning, a victor who is capable of undergoing a further metamorphosis. In overcoming man's nihilism, as it was embodied in HAL, Dave has achieved the second of Zarathustra's three metamorphoses, and the camel - HAL, the great bearer of weights has been superseded by Bowman - the lion. ${ }^{47}$ What remains, and what this transformation has made possible, is the body's apprehension of its will to power in the thought of the eternal return, a thought of the body by which its heroic actions, and hence its final vestiges of subjectivity are overcome. In this Dave achieves the final metamorphosis, and is reborn as the Star Child.

\section{Jupiter and Beyond the Infinite}

Having overcome HAL, Bowman takes the last remaining pod and follows another monolith into the Star Gate. The Star Gate marks a sharp break in the filmic texture of 2001, as "realism" gives way to an almost entirely abstract rushing of light. These spectacular special effects isolate and elevate traditional sci-fi pyrotechnics to a cosmic ring of fire, a rite of passage from which Bowman will emerge ready to be reborn. ${ }^{48}$ The remarkable Star Gate effects were created by Donald Trumbull by adapting existing experimental film techniques, and are in this respect quite different from the cutting edge studio effects Kubrick employed in the rest of the movie. The Star Gate projects film as a dislocating physical experience, in the spirit of the experimental film makers Paul Sharrits and Stan Brakhage, against the narrative logic and "realism" of Hollywood. ${ }^{49}$ In this sense, and as Jacques Goimard has already pointed out, "2001 is the first film since Griffith's Intolerance to be both a superproduction and an experimental film." ${ }^{50} 2001$ follows in a tradition of American avant-garde film interested in the mystical merge of the unleashed sensual body, found once the body floating on capital and techno-science has been overcome. ${ }^{51}$ Somewhere between the epileptic colour fits of Sharrits' work, and the equally ecstatic twitches of Brakhage's painted lines, on a trajectory extending experiments already made by John Whitney and Jordan Belsen, the never ending zoom of the Star Gate reveals the unknown universe, our new body of stars. ${ }^{52} \mathrm{Brakhage}$ 's idea of 'closed-eye seeing' is appropriate, because the Star Gate wants to teach us about a vision that does not compute, 
that moves us beyond consciousness and the human itself. And to do so thought in a rationalist sense must be attacked. And overcome.

This thoroughly Nietzschean ambition also appears in the hallucinatory quality of the Star Gate, and its evocation of the effects of psychedelic drugs. Although Kubrick claimed never to have experimented with LSD himself, he didn't deny the connection to the Star Gate sequence. ${ }^{53}$ Indeed, it is no surprise that in the second phase of the film's publicity the Nietzschean trajectory of man's overcoming visualised in 2001 is referred to as "the ultimate trip." 54 These two elements (its psychedelic interests, and its debt to experimental film) constitute 2001's "politics of ecstasy", with the Star Gate aiming the corpo-intelligence of cinema against the human. This makes the Star Gate episode a political statement that is both entirely of its time, and the most interesting element of Kubrick's interpretation of Nietzsche. Whether associated with the politics of transformation advocated by Sixties drug gurus such as Timothy Leary and Carlos Castaneda or not, the Star Gate episode (once more, in the tradition of American avantgarde film) clearly suggests that a pulverisation of the self in a sublime experience is the necessary condition for the emergence of the new, for the emergence of the future as such. ${ }^{55}$ This emergence is possible only after our battle with a techno-scientific society of control, and only by defeating this suicide-machine can we begin exploring who we aren't, and go where no human has gone before. In this sense, 2001 is the most sublime and radical hippy film ever made, advocating a process of absolute deterritorialisation untroubled by any sentimental return to essentialist human values. ${ }^{56} 2001$ updates Nietzsche for the sixties, retaining his advocacy of political revolution through radical subjective transformation, while exploring contemporary techniques of personal disintegration.

Bowman enters the Star Gate and begins accelerating into a corridor of light. As the intensity and velocity of these lights increases we cut to a reaction shot of Bowman's face as he holds his eyes wide in seeming shock and awe, before twisting his head in a tortured squint attempting to evade the impossible. This sequence is still in "real time" as it were, moving between a Bowman point of view shot of the Star Gate, and his reaction. Space and time remain intact as the camera connects them in a shot-counter-shot. But these shots also mark the limit of Bowman's endurance, and the next shot of his face is frozen and twisted in horror, desperately trying to escape a vision of what clearly exceeds his ability to comprehend. These freeze-frame shots - 


\section{STEPHEN ZEPKE}

there are four of them - not only show Bowman's trauma, but in being frozen register a disjunction between his point-of-view and our experience, and dislocate the camera's 'objective' view, which now films something whose 'reality' is entirely hallucinatory. As a result what is "seen" in the Star Gate is unhinged from Bowman and from the camera, losing any spatial and temporal coherence. We are emersed in this abstract experience of light, one that fractures the "brain" the monolith originally created for man. With neither a subjective nor objective position from which to reflect on what we see, we are unable to act, and everything becomes a pure vision. The Star Gate takes us to a place existing beyond human experience, a place existing, in fact, and as the film's subtitle tells us, "beyond the infinite".

The Star Gate is therefore the culmination of the film's exploration of our "corporeal intelligence", but unlike the free floating spatial fluidities of weightlessness, the Star Gate is not simply physical dis-orientation but subjective dis-integration, for we no longer know from where we see, nor what we experience. The frozen head shots are now replaced by close-ups of Bowman's eye, which like the rushing landscape shots they intersperse, appear in strange psychedelic colours caused by a special treatment of the film. It means that not only has our identification with Bowman's point of view been fractured, but that the status of the camera as an objective "eye" is overcome in its hallucination. We cannot locate what we see subjectively or objectively; some shots seem to show the birth of galaxies, others microscopic biological events. We are somewhere and nowhere, our body and consciousness replaced by a sensation of chaos; we are a pure visionary experience cut loose from the I. The I has become an eye. This is, in Kantian terms, an experience of the sublime, an experience where, as Deleuze puts it: "My whole structure of perception is in the process of exploding." ${ }^{7}$

Kant argues that in the sublime man's subjectivity is surpassed in an experience of a chaotic Nature: "in what we usually call sublime in nature," he writes, "there is such an utter lack of anything leading to particular objective principles and to forms of nature conforming to them, that it is rather in its chaos that nature most arouses our ideas of the sublime, or in its wildest and most ruleless disarray and devastation, provided it displays magnitude and might." ${ }^{\text {" }}$ Of course for Kant this chaotic nature confirmed the existence of a higher faculty of Ideas, the sublime scrambled sensation to reveal an ideal truth and divine beyond. ${ }^{99}$ As such it falls directly within Nietzsche's sights, as the kind of 
nihilism typical of Romanticism, the all too serious attempt to overcome the body and find redemption in an ideal realm. Here, Nietzsche writes in his well-known critique of Romanticism (which is also a self-critique), the sublime provides the "familiar romantic finale - break, breakdown, return and collapse before an old faith, before the old god." 60 Romanticism and its sublime aesthetic were for Nietzsche, nothing but the "old faith" dressed up as "a new art of metaphysical consolation."

Nothing in Dave's emergence into the Regency room implies his comprehension of an infinite and unchanging metaphysical realm. The Regency room is in fact the stage for the most startling transformations in the film, as we shall see. For Kubrick the sublime experience of the Star Gate does not take us beyond the body, but liberates the body from its last remaining grip on truth, its last remaining nihilism: a phenomenological self-consciousness organised around an invisible beyond. ${ }^{62}$ We can understand the necessity of this sublime transformation in terms of Nietzsche's three metamorphoses of man. In overcoming HAL Bowman has changed humanity from a camel into a lion. HAL was the ultimate camel carrying man towards a nihilistic future in the desert of space. "But," Nietzsche writes, "in the loneliest desert the second metamorphosis occurs: the spirit here becomes a lion; it wants to capture freedom and be lord in its own desert." ${ }^{\prime 3}$ The lion becomes lord when he replaces the ascetic ideals of the camel and its hopes of redemption with his own "I will!" (Nietzsche, 1961, 54) But it is precisely this "I" that remains a problem for Nietzsche, for it implies a subjective will that is partially blocked to the unending and unlimited becoming of life itself. ${ }^{64}$ Similarly, Kubrick presents the sublime elements of the Star Gate sequence as the destruction of subjective integrity necessary for the emergence of the new. ${ }^{65}$ Nevertheless the lion, like Bowman, is the necessary escape velocity required to overcome the human, and once this is achieved the real transformation can begin. Nietzsche puts it simply: "To create new values - even the lion is incapable of that: but to create itself freedom for new creation - that the might of the lion can do." ${ }^{\prime 66}$ Once the lion and its "I will" have been overcome the will to power is expressed without nihilism, without recourse to an extra-dimension. Affirmation has undergone another metamorphosis: "This indeed is the secret of the soul: only when the hero has deserted the soul does there approach it in dreams - the superhero." ${ }^{\prime 67}$ This superhero is, for both Nietzsche and Kubrick, the child. Man reborn. Nietzsche writes: 


\section{STEPHEN ZEPKE}

The child is innocence and forgetfulness, a new beginning, a sport, a self-propelling wheel, a first motion, a sacred Yes.

Yes, a sacred Yes is needed, my brothers, for the sport of creation: the spirit now wills its own will, the spirit sundered from the world now wins its own world. ${ }^{68}$

Bowman emerges from the Star Gate into his own world. A world sundered it seems, from any other world. After the pulverisation of his subjective consciousness in a vision encompassing the unknown rhythms of the chaotic universe, Bowman arrives in the Regency room shaking, shattered. The room is utterly incongruous, as absolutely disjunctive as the appearance of the monolith at the beginning of the film. Nevertheless, Bowman seems to once more pick up the thread, and despite all he has gone through moves out of the pod to explore this new found strangeness. Bowman remains animated by a will, but one unencumbered by time and space and their perceptual conventions. The accelerated aging that Bowman now undergoes is clearly not human, and nor is the fact that he observes this process in a series of cuts in which his visions of the future merely precede, seemingly by seconds, that future becoming present. These images don't show a reconstituting ego, they show Bowman's gaze dissolving time. Bowman is animated by something inhuman, and his non-responsiveness is remarkable. Bowman is simply willing the will to power, which means nothing more than that he wills overcoming, his own will in his own overcoming. And in doing so Dave conjures himself from himself, he jump cuts through his life. A life now shorn of anecdotal incident, interest or even event, other than its own destruction. And as we know, every destruction is the condition of creation.

Dave Bowman has arrived, having passed through his cosmic conflagration, in another womb. Like the brain that gave birth to consciousness in the apes, indeed because of the process this entailed, this is a womb from which Dave will be reborn in a repetition of pure difference, a repetition in which the future will arrive. He goes into the bathroom, still wearing his spacesuit and we hear his breath resonating in our ears; a body is reassembling. He looks in a mirror as he goes and he gets his first shock. He has aged considerably and we can only conclude that time is most severely out of joint. At the moment we seem to have arrived back in diegetic space we immediately experience its temporal logic being disturbed. Not this time from without, by the 
sublime effects of the Star Gate, but from within, from a disjunction in time.

Bowman hears some noise coming from the other room, a soft metallic clinking. He peers around the corner, and once more in a point-of-view shot he sees himself, now very elegantly clothed in a fulllength black dressing gown, with his back to the door eating dinner. The eating Bowman slowly turns around, as if he too had heard a noise, and as we watch him turning a remarkable thing happens: the sound of breathing stops and we are in the impossible position of seeing with Bowman's eyes, but no longer being in his body. We are watching, in other words, our own disappearance. Here is the logical conclusion to our pulverisation in the Star Gate's cosmic vision. It is the condition for Bowman's accelerated transformations and the unhinging of our own identification, once more, both with Bowman and ourselves. For who is Bowman now, and who are we? A vision in which we return, overcome, continually new. The self-propelled wheel announcing a future of eternal return.

Bowman however, forever unflappable, seems to accept this with good grace. No doubt there are consolations as he eats the only decent meal of the entire movie. It is his last supper. Then he accidentally knocks his glass of wine on the floor, the glass of wine whose taste he had just so deliberately savoured. He looks down, we get a close-up of the smashed glass and then we see Bowman staring intently at the pieces. He seems, like the ape and Dr. Floyd before him, to have an idea. Immediately we hear breathing once more, and Bowman looks up and over to its source, revealed to us not in a point of view shot this time, but from behind Bowman's head. We see Bowman become really old and lying in bed. Time once more skips a beat. From here things go fast, as the old man offers the final echo of the creative gesture and raises a feeble arm towards the monolith that now is at the end of his bed. This leads to the man's transformation into the child, whose point of view we once more take as it moves through the monolith and out into the cosmos.

Thus the film ends with this moment of return, as the child floats through the monolith and back to earth, completing man's enormous cycle of metamorphosis. But in fact this figure of return has already been offered by Kubrick in the shot of the smashing glass, which is the completion of the arc of the jaw bone cast high in exultation by the ape ${ }^{69}$ This joyful flight was interrupted, we remember, by the spaceship, by man's techno-scientific ambitions and the nihilistic hubris 


\section{STEPHEN ZEPKE}

of his intelligence. But all this has been overcome, and Bowman has returned us once more to man's genesis, to the secret of the monolith, its will to power. The initial impetus the monolith introduced was that of disjunction, and this disjunction taught that the emergence of the new will always involve the smashing of its containers. So the ape smashed the tapir's skull in becoming a man, so Bowman smashed HAL, and so man's (self) consciousness must finally be smashed if he is to be reborn a Star Child, and return innocence to earth. And each overcoming is ushered in by the monolith, by the eternal return of an interruption, of a difference creating something new. The monolith, in other words, is the immanent outside of our future, a future unconditioned by the past or the present because it repudiates them at the same time as they produce it. The relentless forward momentum of 2001 offers the same figure; every question posed by metamorphosis finds its answer in an absolute affirmation of what is new. Here Kubrick is close to Deleuze's 1968 reading of the eternal return:

[Eternal return] is properly called a belief of the future, a belief in the future. Eternal return affects only the new, what is produced under the condition of default and by the intermediary of metamorphosis. However, it causes neither the condition nor the agent to return: on the contrary it repudiates these and expels them with all its centrifugal force. [...] It is itself the new, complete novelty. ${ }^{70}$

The monolith is our future, it is the eternal return of will to power as such, the will that wills itself. But the monolith and what has become of man merge in the final sequence of the film as both are overcome and the Star Child is born. "I tell you: one must have chaos in one, to give birth to a dancing star." ${ }^{\text {"71 }}$ This is the announcement of the broken glass: it was no accident that it was the only significant accident to occur in a film so incredibly deliberate. ${ }^{72}$ The smashed glass rings the return of the unaccountable, of chance, of the violent disjunction of overcoming that disturbs man's most deliberate, most brilliant, and most nihilistic thought. It ushers on stage the Star Child as the innocence and forgetfulness of becoming, as an embodiment of will to power, it's bulging eyes emphasising the majesty of its vision. This is the vision the intelligence of man and the void of the monolith gave birth to, a vision they could never contain. The genealogy is complete, the human has been overcome and it is Noontide once more.

As the Star child returns the future to the earth, so Kubrick 


\section{AGAINST NIHILISM}

returns the future to us, revalued. 2001 reopens cinema - and sciencefiction in particular - onto the horizon of revolution. As such it is one of those beautiful fruits of 1968 whose inheritance we are yet to taste. It is revolution as the affirmation of our bodies over nihilism, of our instinctual actions over consciousness, and of the necessity of our overcoming. ${ }^{73}$

\section{Notes}

${ }^{1}$ Friedrich Nietzsche. Thus Spoke Zarathustra. Trans. R. Hollingdale. London: Penguin, 1961, p. 336.

${ }^{2}$ For an account of Deleuze's relation to Nietzsche in terms of Science-Fiction and a philosophy of the future see Gregory Flaxman's excellent essay 'sci-Phi: Gilles Deleuze and the Future of Philosophy,' in Delenze, Guattari and the Production of the New. Eds S. O'Sullivan and S. Zepke. London: Continuum, 2008.

${ }^{3}$ Gilles Deleuze. Cinema 2 TheTime-Image. Trans. H. Tomlinson and R. Galeta. Minneapolis: University of Minnesota Press, 1989, pp. 205-6.

${ }^{4}$ I can't resist quoting Kubrick himself here, and what is a beautiful understatement: "The idea of the magical alignment of the sun, the earth, and the moon, or of Jupiter and its moons, was used throughout the film to represent something magical and important about to happen" (quoted in Michel Chion, Kubrick's Cinema Odyssey. Trans. C. Gorbman. London: bfi publishing, p. 139).

${ }^{5}$ Nietzsche, Thus Spoke Zarathustra, p. 85. There are many variants on this theme in Zarathustra. For example: "For the creator himself to be the child new-born he must also be willing to be the mother and endure the mother's pain" (p. 111) and "only where there are graves are there resurrections" (p. 136).

${ }^{6}$ Nietzsche clearly associates will to power, overcoming and life: "Where I found a living creature, there I found will to power; [...] And life itself told me this secret: 'Behold,' it said, 'I am that which must overcome itself again and again."' (Nietzsche, Zarathustra, pp. 137-38, italics added).

${ }^{7}$ Michel Chion suggests that the monolith and the discontinuous narrative structure of 2001 are "intimately related" (Chion, Kubrick's Cinema Odyssey, p. 72). Each part of 2001, he argues, "is subtended by the idea of an after and ends with a beginning: the beginning of man, the awakening of the monolith on the moon, the revelation to Dave of the monolith and another species beside man, the possible beginning of a new species of superman" (p. 69). This relentless surge into the future each time the monolith appears is, Chion perceptively argues, the narrative correlate of the monolith's disjunctive energy. Chion will, however, go on to argue that these structural 


\section{STEPHEN ZEPKE}

disjunctions "produce an effect of arbitrariness" that "institutes the acquisition of language," a language that is the films as much as ours, and that establishes the monolith's function as primary castration (p. 177). Chion's subtle analysis of 2001 along psychoanalytic lines nevertheless has two major drawbacks; it places an emphasis on language that the film itself seems to deny (there is only around 40 minutes of dialogue in the two hour 28 minute long film), and it fails to really account for the "psychotic" final episode of the film. Chion claims the Stargate passage indicates and inculcates a power of "wonder" at the "mystery" of life (p. 150), a mystery that remains linguistic inasmuch as it is defined by its "unlimited meaning" (p. 151). Although this fits well with Chion's psychoanalytical commitments, and his belief that "the film is directly about interpretation itself" (p. 138), it means he must abandon any Nietzschean explanation, as he writes, 2001 "is far from any mythology of the superman" (p. 151). Not only does the film draw on Nietzsche far too often and precisely for this to be true, but by embracing the Nietzschean "meaning" of the film it is possible to affirm it in the highest possible terms, as an ontological revaluation of Science Fiction that contributes a new concept of the future. Or at least this is what the rest of this essay shall attempt to argue.

${ }^{8}$ This line seems to have escaped Jerold Adams, who claims that "we know who our creators and designers really are - namely, the aliens" to support his argument that 2001 draws on Nietzsche's proclamation of the death of God. Neither claim is sustainable because at no point of the film is anyone aware of the monolith's function (Jerold Adams, "Nietzsche's Overman as Posthumous Star Child in 2001: A Space Odyseey," in the Philosophy of Stanley Kubrick. Edited by J.J. Adams. Lexington: The University Press of Kentucky, 2007, p. 251).

${ }^{9}$ Friedrich Nietzsche. The Will to Power. Trans. W. Kaufman and R. Hollingdale. New York: Vintage, 1967, p. 284.

${ }^{10}$ Friedrich Nietzsche. On the Genealogy of Morals. Trans. W. Kaufmann. New York: Vintage, 1967, p. 20.

${ }^{11}$ Gene Youngblood. Expanded Cinema. New York: E. P. Dutton and Co., 1970, p. 141.

${ }^{12}$ Nietzsche, Genealogy of Morals, pp., 40, 86.

${ }^{13}$ Ibid., p. 87.

${ }^{14}$ Ibid., p. 67.

${ }^{15}$ Ibid., p. 85.

${ }^{16}$ Ibid.

${ }^{17}$ Ibid.

${ }^{18}$ The first four spacecraft we are shown are all atomic weapons circling the globe, a point not immediately obvious in the film, but made clear in the book. 


\section{AGAINST NIHILISM}

${ }^{19}$ As Chion accurately points out, the warfare of the apes has been superseded by mutual surveillance (Chion, Kubrick's Cinema Odyssey, p. 146).

${ }^{20}$ Pierre Klossowski. Nietzsche and the Vicious Circle. Trans. D. Smith. Chicago: University of Chicago Press, 1997, p. 149.

${ }^{21}$ Nietzsche, Will to Power, pp. 463-4.

${ }^{22}$ This process, once more, is that of the techno-scientific economy, which Kubrick presents - in a vision as prescient as Nietzsche's - as a logical extension of our own state of globalised capital. Nietzsche's words could be Kubrick's: "It is clear, what I combat is economic optimism: as if increasing expenditure of everybody must necessarily involve the increasing welfare of everybody. The opposite seems to me the case: expenditure of everybody amounts to a collective loss: man is diminished - so one no longer knows what aim this tremendous process has served. An aim? A new aim? - that is what humanity needs" (Nietzsche, Will to Power, p. 866). Kubrick will show us its aim - HAL - and the new aim it serves - HAL's overcoming.

${ }^{23}$ See Friedrich Nietzsche, Zarathustra, "On the Spirit of Gravity."

${ }^{24}$ Dave Bowman is in fact asked this question in the course of the interview. To which he answers, "Well, he acts like he has genuine emotions. [...] But as to whether or not he has real feelings, I don"t think anyone can truthfully answer."

${ }^{25}$ By 1968 the technophobia sub-genre of science fiction films was already well developed. The Day the Earth Stood Still (1951, Robert Wise) explored the moral dangers of science to man, and had shown these trumped, or even cured by a superior "alien" technology beyond human understanding. In a way 2001 replays this story-line, although with an anti-technoscience twist. Similarly, The Forbidden Planet (1956, Fred McLeod Wilcox) contrasts the emotionally driven human with a super-intelligent alien race, the Krel, that has mysteriously died out, but whose moral lesson nevertheless remains to be learnt. 2001 also echoes this story-line, whose moral is that the hubris of technological perfection unleashes uncontrollable "monsters of the id." This is also Nietzsche's argument about scientific knowledge, as we shall see: "Our whole attitude toward nature, the way we violate her with the aid of machines and the heedless inventiveness of our technicians and engineers, is bubris' (Nietzsche, Genealogy of Morals, p. 113).

${ }^{26}$ This confirms our first impression of the Discovery, which passed before our eyes like nothing so much as a brain and spinal column floating in space.

${ }^{27}$ I take the term homo machinus from the allegorical interpretation of Leonard Wheat, who provides the most exhaustive argument that 2001 is a systematic dramatisation of both Homer's Odysseus, and Nietzsche's Zarathustra. The problem with this account is that it attempts to read almost every scene of the film as a dramatisation of its two source texts, but this is done at the expense of any deeper understanding. As a result, Wheat quips, 


\section{STEPHEN ZEPKE}

"2001 is like a boys game of code-making and breaking." 'This produces an at times ridiculous interpretation of the film: "The character symbolized by Floyd is symbolically absorbing whatever the monolith symbolically represents" (Wheat, Kubrick's 2001 A Triple Allegory. Lanham, Maryland and London: The Scarecrow Press, 2000, pp. 21-22). Unfortunately this style of interpretation is rife in 2001-studies. Some follow Wheat's analysis, such as Abrams discussion of whether it is Bowman or Poole who symbolise Nietzsche's tightrope walker (Jerold Abrams, "Nietzsche's Starchild as Posthuman Overman in 2001: A Space Odyssey," p. 254. Others attempt to find their own "source" texts for the film. Joseph Gelnius, in a 1969 review suggests Marshall McCluhan and a book by British Jungian psychiatrist Alan MacGlashan, The Savage and Beautiful Country. Morris Beja, in a review from 1968 suggests Yeat's poem 'sailing to Byzantium" which emphasises 2000 year historical cycles. And Robert Plank puts forward Antoine de SaintExpuery's poem "Citadelle", which contains the lines "but the block of granite, dripping with a luminous rain, remained, for me, impenetrable." The point is not so much whether these texts were or were not "sources", Kubrick's researching was voracious and wide-ranging and could well have included almost anything, rather the problem with such interpretations is their stubborn ignorance as to the explicitely philosophical themes of the film, which do not fall under the compass of their attempts at "code-breaking".

${ }^{28}$ Nietzsche, Genealogy of Morals, p. 119

${ }^{29}$ Ironically Nietzsche employs a science fiction idiom in describing it: "Read from a distant star, the majuscule script of our earthly existence would lead to the conclusion that the earth was the distinctively ascetic planet, a nook of disgruntled, arrogant, and offensive creatures filled with a profound disgust at themselves, at the earth, at all life, who inflict as much pain on themselves as they possibly can out of pleasure in inflicting pain - which is their only pleasure. [...] For an ascetic life is a self-contradiction: here rules a ressentiment without equal, that of an insatiable instinct and power - will that wants to become master not over something in life but over life itself, over its most profound, powerful, and basic conditions; here an attempt is made to block up the wells of force; here physiological well-being itself is viewed askance, and especially the outward expression of this well-being, beauty and joy; while pleasure is felt and sought in ill-constitutedness, decay, pain, mischance, ugliness, voluntary deprivation, self-mortification, self-flagellation, selfsacrifice. All this is in the highest degree paradoxical: we stand before a discord that wants to be discordant, that enjoys itself in this suffering and even grows more self-confident and triumphant the more its own presuppositions, its physiological capacity for life, decreases" (Nietzsche, Genealogy of Morals, pp. 117-118). For a cinematic affirmation of the necessary convergence of science and religion in a faith in the big beyond, see Contact (1997, Robert Zemeckis).

${ }^{30}$ Genealogy of Morals, p. 147. 


\section{AGAINST NIHILISM}

${ }^{31}$ Ibid., p. 150.

${ }^{32}$ Ibid., p. 151.

${ }^{33}$ Ibid., p. 163.

${ }^{34}$ Ibid., p. 161. Nietzsche had already posed himself as the answer to this question, a question and answer he refers to in The Gay Science: "The will to truth requires a critique - let us thus define our own task - the value of truth must for once be experimentally called into question." (Nietzsche, The Gay Science. Trans. W. Kaufmann. New York: Vintage, 1974, paragraph 344).

${ }^{35}$ Nietzsche, Genealogy of Morals, p. 161. Klossowski elaborates the meaning of this necessity for Nietzsche's prescient vision of the future: " $[\mathrm{F}]$ or everything that may want to preserve itself at a certain degree, whether a society or an individual, the will to power appears essentially as a principle of disequilibrium. And insofar as knowledge accompanies power and increases in proportion to acquired power, knowledge (and thus culture as well) must in turn disrupt the equilibrium of a determined state, however, says Nietzsche, knowledge will never be anything more than an instrument of conservation - for there will always be a discordance between the excess of (the will to) power and the feeling of security that knowledge procures" (Klossowski, Nietzsche, p. 103).

${ }^{36}$ Fredric Jameson, Archaeologies of the Future, The Desire Called Utopia and Other Science Fictions. London and New York: Verso, 2005, p. 114.

${ }^{37}$ This element of the narrative is made explicit in the book. I have only read the book after having completed this essay, and do not wish to enter into the intricacies of their differences. Nevertheless, the film is very vague about HAL's motivations. Self-preservation does not explain HAL's first predatory move, which is more to do with a cold, scientific will-tonothingness. The book is also more explicit about the motivations of the story's other characters, including those of the monolith. Needless to say, the film is better than the book.

${ }^{38}$ Nietzsche, The Anti-Christ. Trans. R. Hollingdale. London: Penguin, 1968, p. 194.

${ }^{39}$ Annette Michelson, "Bodies in Space, Film as "Carnal Knowledge", in Artforum, no. 6 (1969), p. 63. Michelson argues: "A weightless world is one in which the basic co-ordinates of horizontality and verticality are suspended. Through that suspension the framework of our sensed and operational reality is dissolved. The consequent challenge presented to the spectator in the instantaneously perceived suspension and frustration of expectations, forces readjustment. The challenge is met almost instantaneously, and consciousness of our own physical necessity is regenerated. We snap to attention, in a new, immediate sense of our earth-bound state, in repossession of those coordinates, only to be suspended, again, toward other occasions and forms of recognition. These constitute the "subplot" of the Odyssey, plotting its action in us" (p. 60). 


\section{STEPHEN ZEPKE}

${ }^{40}$ Ibid., p. 57.

${ }^{41}$ Ibid., p. 59. Kubrick, we know, was worried that the imminent launch of the Apollo mission to the moon would occur before his film's release, making its dramatic presentation of weightlessness redundant, eclipsed by the real as it were.

${ }^{42}$ Ibid., p. 60.

${ }^{43}$ Ibid., p. 61. This "physicality as the ground of consciousness" is of course the Nietzschean assumption of the will to power. Michelson's comment approaches Nietzsche's at this point, but she never really moves beyond the phenomenological assumptions she is working with. Unsurprisingly she hardly deals with the Star Gate in relation to her astronaut's "lived body". There is not the space to develop the confrontation of Nietzsche and Merleau-Ponty here, but suffice to say it would revolve around the status of Merleau-Ponty's "flesh" and its structuration by invisible "Ideas" (Michelson's "corporeal a-prioris"), and the relation of this to the animalbody and its affects that Nietzsche affirms.

${ }^{44}$ Deleuze, Cinema 2, p. 189. Deleuze argues that Kubrick offers us a cinema of the brain, inasmuch as Kubrick's mise en scène is always a brain. This may be true in 2001 to the extent that the spaceship and the final room are both kinds of brains, but this does not contradict the importance of the body for Kubrick, nor their immanence in a body/brain of the future. In this sense 2001 also follows Deleuze's analysis of a cinema of the body. "Life will no longer be made to appear before the categories of thought; thought will be thrown into the categories of life. The categories of life are precisely the attitudes of the body, its postures" (ibid.). Kubrick, at least, explores the new posture of weightlessness.

${ }^{45}$ Klossowski claims that "a corporealising thought" emerges in a body, and is not the property of a self, but the expression of impulses and their chance and chaotic confrontation (Klossowski, Nietssche, pp. 29-30).

${ }^{46}$ This is Deleuze's reading of 2001: "The identity of world and brain, the automaton, does not form a whole, but rather a limit, a membrane which puts an outside and an inside in contact, makes them present to each other, confronts them or makes them clash." Bowman enacts this limit of thought in which the corporeal intelligence of the body/brain is able to produce a new folding of the universe and thought, a "reconciliation" as Deleuze has it, "a regeneration of the membrane which would pacify the outside and the inside, and re-create a world-brain as a whole in the harmony of the spheres. At the end of Space Odyssey, it is in consequence of a fourth dimension that the sphere of the foetus and the sphere of the earth have a chance of entering into a new, incommensurable, unknown relation, which would convert death into a new life" (Cinema 2, p. 206).

${ }^{47}$ Nietzsche, Zarathustra, "Of the Three Metamorphoses." 


\section{AGAINST NIHILISM}

${ }^{48}$ In an interesting essay Carl Freeman suggests that sci-fi cinema's special effects are the epitome of capital's control of our corporeality that works against our critical intellect. 2001, he argues, foregrounds "the spiritual nullity" of this control and, "in classic dialectical fashion" opposes it to "literary science fiction [...] as the critical genre par excellence" (Freeman, "The Possibility of a Science-Fiction Cinema," in Science-Fiction Studies, Volume 25 [1998]. p. 312). As a result 2001attains the remarkable achievement of revealing the "hopeless contradiction between science fiction and cinema" and shows that science fiction film "may well be intrinsically impossible" (Freeman 315). Freeman's determination to locate all critical intelligence in a dialectical process of thought, and all political possibility in science fiction literature means that he misses how Kubrick locates the body - precisely the body controlled by capital - against the critical intelligence of HAL. But this revolt nevertheless requires the Star Gate in order to turn special effects against itself, a liberation achieved by Kubrick's turn from studio technology to the work of American experimental film-makers. Kubrick's “critical” (this time in Nietzsche's sense) use of special effects explores a non-dialectical corpo-intelligence in a way perhaps only cinema can. 2001 - and cinema - explores a different political body to that imagined by Freeman's dialectical Marxism.

${ }^{49}$ These artists explored the possibilities of the non-narrative and unconscious physicality of the filmic experience, the way film is capable of turning the body on and the brain off. This exploration of "corpo-intelligence" was a line of research both coming out of and extending the counter cultural ambitions for psychedelic drug use. In this sense I see the Star Gate episode in 2001 to be generally consistent with the aims and strategies of the experimental film tradition upon which it drew.

${ }^{50}$ Quoted in Chion, Kubrick's Cinema Odyssey, p. 41.

${ }^{51}$ Michelson also examines 2001's place in the avant-garde tradition, comparing it to, amongst others, Leger's Ballet Mechanique (Michelson. "Bodies in Space," p. 60).

${ }^{52}$ For a discussion of 2001's relation to contemporary experimental film practices, and to psychedelic drug use, see Youngblood, Expanded Cinema, pp. 141-154.

${ }^{53}$ Vincent LaBrutto, Stanley Kubrick. London: Faber and Faber, 1997, p. 313.

${ }^{54}$ It would be interesting to pursue the relations between the growing availability of Nietzsche in English and the American counter-culture of the sixties. R. J. Hollingdale's translation of Thus Spoke Zarathustra was published by Penguin in 1961, and Walter Kaufman's translation of Will to Power and On the Genealogy of Morals (with R. J. Hollingdale) came out in 1967.

${ }^{55}$ In this sense 2001 seems to accord with Nietzsche's own rejection in Zarathustra of his claim in The Birth of Tragedy that the means of radical cultural change are immanent in received historical circumstances. In this 


\section{STEPHEN ZEPKE}

sense both Nietzsche and Kubrick argue that transformation is an immanent force, but one that is nevertheless necessarily external to historical circumstances.

${ }^{56}$ Such sentiments were found in other "trip" films of the time, such as Easy Rider (1969, Dennis Hopper), or the later Altered States (1980, Ken Russell). In fact, in its attack on bourgeois humanism - and hence as a true "68 film" - 2001 finds its closest allies in European films of the time such as Jean-Luc Godard's Weekend (1967), Michelangelo Antonioni’s IlDeserto Rosso (1964), and Zabriskie Point (1970), and Pier Paolo Pasolini’s Theorem (1968), and Porcile (1969). All of these explored the possibilities of a hallucinatory deterritorialisation of traditional subjectivities under the forces of capital (Godard), of madness (Antonioni), and of sexual love (Pasolini).

${ }^{57}$ Gilles Deleuze, Third lesson on Kant, seminar, 28 March 1978. Trans. M. McMahon. Unpaginated. Found at www.imaginet.fr/deleuze.

${ }^{58}$ Immanuel Kant, Critique of Judgement. Trans. Werner S. Pluhar. Indianapolis: Hackett Publishing Company, 1987, pp. 99-100.

59 "Sublime is what even to be able to think proves that the mind has a power surpassing any standard of sense" (Kant 106). Similarly, "The sublime can be described thus: it is an object (of nature) the presentation of which determines the mind to think of nature's inability to attain to an exbibition of ideas" (Kant, Critique of Judgement, p. 127). See Flaxman for an account of Deleuze's understanding and use of Kant's sublime.

${ }^{60}$ Nietzsche is criticising his own The Birth of Tragedy here, in the second preface he wrote for that work in 1886, "Attempt At A Self-Criticism". Nevertheless his comments can be taken as a statement against Romanticism in general.

${ }^{61}$ Friedrich Nietzsche, "Attempt At A Self-Criticism," in The Birth of Tragedy. Trans. R. Hollingdale. London: Penguin, 1993.

${ }^{62}$ Kubrick would here be close to Deleuze's highly original use of the sublime in Cinema 2, The Time-Image. There he suggests the destruction of the sensory-motor apparatus in cinema after the war, and the emergence of the time-image was a sublime achievement. "Romanticism had already set out this aim for itself:" he writes, "grasping the intolerable or the unbearable, the empire of poverty, and thereby becoming visionary, to produce a means of knowledge and action out of pure vision" (Cinema 2, p. 18). Deleuze develops this "sublime" element in his own way of course, carefully removed from any Romantic redemption.

${ }^{63}$ Nietzsche Zarathustra, p. 54.

64 " $H$ is deed itself is still the shadow upon him: the hand darkens the doer. He has still not overcome his deed. To be sure, I love in him the neck of the ox: but now I want to see the eye of the angel, too. He must unlearn his heroic will, too: he should be an exalted man and not only a sublime one - the ether itself should raise him up, the will-less one! He has 


\section{AGAINST NIHILISM}

tamed monsters and solved riddles: but he should also redeem his monsters and riddles, he should transform them into heavenly children" (Ibid., p. 140).

${ }^{65}$ In an interesting essay Scott Bukatman suggests something similar: "The passage through the Star Gate is a voyage 'beyond the infinite': a movement beyond anthropocentric experience and understanding. [...] In 2001, light's transformative power illustrates, embodies and enacts precisely the supersession of the human (and the human's rebirth as a super-human, a Star Child)" (Bukatman, "The Artificial Infinite: On Special Effects and the Sublime", in Alien Zone II, The Spaces of Science Fiction Cinema. Ed. A. Kuhn. London and New York: Verso , 1999, pp. 263-4).

${ }^{66}$ Nietzsche Zarathustra, p. 55.

${ }^{67}$ Ibid., p. 141.

${ }^{68}$ Ibid., p. 55.

${ }^{69}$ A point made by Chion, Kubrick's Cinema Odyssey, p. 119.

${ }^{70}$ Deleuze Difference and Repetition. Trans. P. Patton. New York: Columbia University Press, 1994, p. 90.

${ }^{71}$ Nietzsche, Zarathustra, p. 46.

${ }^{72}$ There are two other rather inconsequential accidents that I can think of: the man meeting Dr. Floyd on the Space Station is slightly late, and Dave burns his fingers while getting dinner on the Discovery. Neither accident is dwelt upon in the way the broken glass is.

${ }^{73} \mathrm{I}$ would like to thank Arturo Silva for his inspiration and collaboration on this essay. Without him it wouldn't have started, and without his insights it wouldn't have been half as good. I would also like to thank Petar Milat at MAMA, Zagreb, who first invited me to present this material there, and published an earlier version of it in Viqualni Kolegij Zbornik, (Zagreb: Multimedia Institute, 2008). 